\title{
Effect of Zeolite on the Water Quality and Growth Performance of Red Hybrid Tilapia (Oreochromis niloticus)
}

\author{
Rabiatul Adawiyah Meor Mohamad Zain ${ }^{1}$, Nur Farrah Izzaty Shaari², Mohamad Faiz Mohd \\ Amin $^{3}$, Musfiroh Jani ${ }^{4}$ \\ \{adawiyahmeor@gmail.com ${ }^{1}$,musfiroh@umk.edu.my ${ }^{4}$ \} \\ 1,2,3,4Faculty of Earth Science (FSB), Universiti Malaysia Kelantan, Jeli Campus, 17600 Jeli, Kelantan, \\ Malaysia.
}

\begin{abstract}
Water quality is a critical factor in fish farming. Optimal water quality varies by species and must be monitored to ensure fish growth and survival. In the present study, the effects of zeolite on the water quality and growth performance of Red Hybrid Tilapia (Oreochromisniloticus) were investigated. The study was conducted in an aquarium with capacity of 30 liter of water and 20 tilapia fry. Zeolite was place inside a net bag with amount of 0 (control), 5, 10, 15, $20 \mathrm{~g} / \mathrm{L}$ added into the water and carried out in 60 days. The obtained result showed that ammonia, nitrite, and nitrite levels were significantly reduced in treated water compared with control. The lowest ammonia levels recorded in $15 \mathrm{~g} / \mathrm{L}$ treatment of zeolite, consistent with nitrite and nitrate. However for total phosphorus and organic phosphorus (orthophosphates), the lowest concentration obtained was from addition of $10 \mathrm{~g} / \mathrm{L}$ of zeolite. At the end of study, the average body weights of fish in control $(0 \mathrm{~g} / \mathrm{L}), 5 \mathrm{~g} / \mathrm{L}, 10 \mathrm{~g} / \mathrm{L}, 15 \mathrm{~g} / \mathrm{L}$ and $20 \mathrm{~g} / \mathrm{L}$ zeolite were $20.9 \pm 4.2 \mathrm{~g}$, $21.5 \pm 2.6 \mathrm{~g}, 22.3 \pm 1.7 \mathrm{~g}, 22.6 \pm 2.1 \mathrm{~g}$ and $27.7 \pm 2.8 \mathrm{~g}$ respectively. On the other hand, average total lengths were $9.5 \pm 1.7 \mathrm{~cm}, 9.6 \pm 1.7 \mathrm{~cm}, 9.9 \pm 1.9 \mathrm{~cm}, 10.0 \pm 1.8 \mathrm{~cm}$ and $10.9 \pm 1.9 \mathrm{~cm}$. Thus, the addition of zeolite is significant for the improvement of water quality and growth performance of Red Hybrid Tilapia (Oreochromisniloticus).
\end{abstract}

Keywords: Zeolite, Oreochromisniloticus, Red hybrid tilapia, Water quality, Growth performance.

\section{Introduction}

In recent years, production of freshwater fish is increased in Malaysia. This is due to the higher consumption of food fish that has increased by $150 \%$ since 1961 (FAO, 2013). The common species are keli, patin and tilapia which can also be processed into convenience products rather than being sold fresh. Amongthe commercially cultured freshwater species, red tilapia, Oreochromissp., is one of the popular aquaculture species in Asia including Malaysia. Red tilapia has high demand and value in the market due to its taste and competitive price. The figure set by the Malaysian Department of Fisheries (DoF), stated that around 35,400tons of tilapia, worth MYR 248 million in production value were recorded in the country last year. In the next four years, DoF aims to increase production to 60,000tons; 70\% by 2020 . On top of that, water quality is the main factor in determining the optimum production of freshwater fish farming. The concentration of total ammonia nitrogen (TAN) is the key limiting water quality parameter in aquaculture. In close or recirculating systems for aquaculture such as tank and aquariums, the causes of diseases and fish mortalities come from ammonia that produced by the decomposition of excreta and unfed fish feed(El-Gendy et al., 
2015). Ammonia nitrogen is the major pollutant in aquaculture system that is toxic to fish and can give detrimental effect to the growth and health of fish. Therefore, it is important to remove ammonia in water and in a meantime improve the water quality of fish farming systems.

Nitrification and ion exchange are two of the principal methods in removing ammonia. Material such as oyster shell, rock, sand, activated carbon and others are used to prepare as a substrate for the bacteria involved in nitrification process. Meanwhile, ion exchange is a process in which ions from a synthetic or natural resin are exchanged with specific ions in wastewater. Some natural resin, such as zeolite, is used in removing ammonia from wastewater and clinoptilolite is one of the best zeolites in ammonia removal ion exchange process (Emadi et al., 2001; Farhangi \& Rostami-Charati, 2012). Zeolites are microporous crystalline hydrated aluminosilicates, which have been used in various applications due to their unique physicochemical characteristics such as ion exchange and adsorption-desorption properties (Ghasemi et al., 2016). According to Y1ldırım et al. (2009), there are three main functions of natural zeolite benefits to aquacultures. It acts as an adsorbent for removing ammonia from the pond water that can improve water quality, enriching the ventilating system with oxygen in the aquarium and by using as a feed additive in feed rations that will improve the fish growth and health. In previous study, addition of $12 \mathrm{~g} / \mathrm{L}$ zeolite could prevent the mortality of Acipenserpersicus. The survival rate of fish also increased with increasing of zeolite concentration (Farhangi \& Rostami-Charati, 2012). In addition, clinoptilolite has been used during ornamental fish transportation because of the effectiveness to remove ammonia.

Shrimp culture in Thailand and other Asian countries, had commonly applied zeolite to the ponds to lower the TAN concentrations by adding 180 to $350 \mathrm{~kg}$ per ha of zeolite into the ponds which culture animals are exposed, but there is no research findings to support this practices (Zhou \& Boyd, 2014). Even though there were many research conducted on the application of zeolite in fish culture, there is no specific dosage for specific fish culture. On top of that, it is considered to be an obstacle in application of zeolite for large-scale aquaculture (Ghasemi et al., 2016). The specific dose of zeolite is impossible to be recommended especially in fish rearing system. The dose of zeolite is depending on such factors as the stocking density of fish, protein content in feed, feed stability and definitely the quality of water (Abdel-Rahim, 2017). This study aims to investigate the effect of different dose of zeolite on the growth performance of Red hybrid Tilapia (Oreochromisniloticus) and the quality of water.

\section{Materials And Methods}

This research was conducted in Aquaculture Laboratory, University Malaysia Kelantan Jeli Campus, Kelantan for 60 days.

\subsection{Experimental Design}

Group of twenty Red Hybrid Tilapia (Oreochromisniloticus) fry (2-3 inch) had been stocked in fifteen aquarium of 30 litre capacity. These aquariums were filled with tap water and anti-chlorine was added to prevent the mortality of the fish and also to purify the water from chlorine. Constant aeration was prepared for each aquarium to supply oxygen for the fish. Each aquarium was assigned a different dose $(0,5,10,15,20 \mathrm{~g} / \mathrm{L})$ of zeolite $(2-5 \mathrm{~mm}$ in size) in triplicate. The zeolite was inserted in a suspended cloth bag before placed into the aquarium to prevent coarse particles inside aquarium water from obstructing the pores of zeolite and decreasing ammonium retention (Oz et al., 2016). In this study, Indonesian zeolite, 
clinoptilolite type was used with chemical compositions as shown in Table 1. The fish was fed with commercial feed two times daily, each time $2 \%$ of average body weight.

Table 1. Chemical composition of zeolite

\begin{tabular}{ll}
\hline Elements & Percentage (\%) \\
\hline $\mathrm{SiO}_{2}$ (Silicon Oxide) & 71.10 \\
\hline $\mathrm{Al}_{2} \mathrm{O}_{3}$ (Aluminium Oxide) & 13.12 \\
\hline $\mathrm{Fe}_{2} \mathrm{O}_{3}$ (Iron III Oxide) & 0.91 \\
\hline $\mathrm{TiO}$ (Titanium Oxide) & 0.01 \\
\hline $\mathrm{CaO}$ (Calcium Oxide) & 1.54 \\
\hline $\mathrm{MgO}$ (Magnesium Oxide) & 0.99 \\
\hline $\mathrm{K}_{2} \mathrm{O}$ (Potassium Oxide) & 2.40 \\
\hline $\mathrm{Na}_{2} \mathrm{O}$ (Sodium Oxide) & 0.90 \\
\hline $\mathrm{pH}$ & $7-8$ \\
\hline Loss of ignition & 8.72 \\
\hline Cation capacity exchange (CEC) & $100-160 \mathrm{meq} / 100 \mathrm{~g}$ \\
\hline
\end{tabular}

\subsection{Water Quality Parameter}

Physico-chemical water quality in the experimental aquariums was monitored weekly between 09:00 and 10:00 $\mathrm{h}$ each sampling day. The physical parameters monitored were temperature, dissolved oxygen (DO), $\mathrm{pH}$ and turbidity. All parameters were measured by using portable multiparameter, YSI model 556 Mpsexcept for turbidity. Portable turbidity meter HACH model 2100Q was used to measure turbidity. Composite column water samples were collected in $500 \mathrm{ml}$ polyethylene bottle, and analysed for total ammonia nitrogen (salicylate method), nitrite-N (diazotization method), nitrate-N (cadmium reduction method), total phosphorus (acid persulfate digestion method) and reactive phosphorus/orthophosphate (ascorbic acid method) by using HACH DR 6000, UV-Vis Spectrometer following USEPA standard method. Meanwhile for total alkalinity (phenolphthalein \& total method) and total hardness (EDTA method) were tested by using digital titrator.

\subsection{Growth Performance Parameter}

Random fish samples from each aquarium were taken biweekly for growth performance analysis throughout the whole experiment. Growth performance parameters were determined by using the following equations:

i) Weight gain $(\mathrm{WG})=$ Final weight $(\mathrm{g})$ - Initial weight $(\mathrm{g})$

ii) Average daily weight gain $(\mathrm{ADG})=$ Weight gain $(\mathrm{g}) /$ times (days)

iii) Specific growth rate $(\mathrm{SGR})=(\log$ of final weight $(\mathrm{g})-\log$ of initial weight $(\mathrm{g}) \times 100 /$ times (days)

\subsection{Statistical Analysis}

Statistical analysis was carried out by using Microsoft EXCEL 2010 and SPSS statistical package program version 20. One-way ANOVA was used for data analysis. 


\section{Results And Discussion}

\subsection{Water Quality Parameter}

Table 2 shows the average values of the water quality monitored throughout the experimental period. During the experiment, the lowest temperature among the groups was measured at $24.58{ }^{\circ} \mathrm{C}$ and the highest was recorded at $26.88{ }^{\circ} \mathrm{C}$. Average temperature for control, $5 \mathrm{~g} / \mathrm{L}, 10 \mathrm{~g} / \mathrm{L}, 15 \mathrm{~g} / \mathrm{L}$ and $20 \mathrm{~g} / \mathrm{L}$ of zeolite were $25.68 \pm 0.75,25.99 \pm 0.87,25.85 \pm 0.83$, $25.76 \pm 0.80$ and $25.79 \pm 0.89$ respectively and they were within the limits of optimal survival and growth of Tilapia (Popma, 1999; Yıldırım et al., 2009). Throughout the experiment, DO and $\mathrm{pH}$ were measured at their lowest levels as $1.67 \mathrm{mg} / \mathrm{L}$ and 6.62 and the highest was recorded as $4.16 \mathrm{mg} / \mathrm{L}$ and 7.25. In general, tilapia can survive in $\mathrm{pH}$ ranging from 5 to 10 but do best in a $\mathrm{pH}$ range of 6 to 9 . In addition, $\mathrm{pH}$ is an important parameter affecting the sorption process at the water-adsorbent interfaces(Mazloomi \& Jalali, 2016). It was reported that optimal $\mathrm{pH}$ values for ammonia sorption by natural zeolite were in the range of 5-8 (Huang et al., 2010; Mazloomi \& Jalali, 2016; Zhang et al., 2011). This behaviour can be described by the fact that at $\mathrm{pH}$ values above 7.0 , the $\mathrm{NH}_{4}{ }^{+}$is converted into unionizedammonia $\left(\mathrm{NH}_{3}\right)$ and the $\mathrm{NH}_{3}$ molecules cannot exchange back into the zeolite and thus strips with air. The $\mathrm{pH}$ values obtained during this experiment were within the range. Meanwhile the tolerable limits of dissolved oxygen for tilapia is between 3.0-4.0 mg/L (Popma, 1999). But the DO values were below the limits except for treatment with $15 \mathrm{~g} / \mathrm{L}$ zeolite. This was due to the high concentration of ammonia (Table 2).Mokhtari-Hosseini et al. (2016) stated that the existence of ammonium ion in water can cause the depletion of dissolved oxygen levels in water. Besides, the highest and lowest turbidity was recorded at $17.55 \mathrm{NTU}$ and $9.99 \mathrm{NTU}$ in addition of $20 \mathrm{~g} / \mathrm{L}$ and, $15 \mathrm{~g} / \mathrm{L}$ of zeolite respectively. The other treatments seemed to be constant for turbidity levels.

The average ammonia concentration, in the groups with addition of $5 \mathrm{~g} / \mathrm{L}, 10 \mathrm{~g} / \mathrm{L}, 15 \mathrm{~g} / \mathrm{L}$ and $20 \mathrm{~g} / \mathrm{L}$ zeolite, was found to be at $0.17 \mathrm{mg} / \mathrm{L}, 0.11 \mathrm{mg} / \mathrm{L}, 0.04 \mathrm{mg} / \mathrm{L}$ and $0.0 .8 \mathrm{mg} / \mathrm{L}$, respectively, and the highest value recorded $(0.18 \mathrm{mg} / \mathrm{L})$ in control group (Table 2). Ammonia concentration in the groups that were added with $15 \mathrm{~g} / \mathrm{L}$ and $20 \mathrm{~g} / \mathrm{L}$ zeolite was found to be relatively lower $(\mathrm{p}<0.05)$ than control. Thus it was found that addition of natural zeolite had a positive effect in terms of reducing the ammonia concentration levels in water. This result was consistent with (Danabas \& Altun, 2011; Ghiasi \& Jasour, 2012). In addition, Oz et al., (2016) found that addition of zeolite inside or outside net bag had reduced the concentration of ammonia in aquarium water. However, the use of zeolite in a net bag gave more advantages in terms of high adsorption levels of ammonia. Zeolite exchanges sodium ions for ammonium ions and shifts the ammonia equilibrium away from toxic un-ionized ammonia, thus preventing an increase in its level (Ghiasi \& Jasour, 2012). It was reported that toxicity of unionized ammonia (NH3) for short-term exposure usually lie between 0.6 and $2.0 \mathrm{mg} / \mathrm{L}$ for pond fish, and sub-lethal effects may occur at 0.1 to $0.3 \mathrm{mg} / \mathrm{L}$. It was recommended that the tolerable limits of ammonia should be lower than $0.2 \mathrm{mg} / \mathrm{L}$ for pond fishery (Bhatnagar \& Devi, 2013).

The lowest concentration of nitrite was recorded at $0.23 \mathrm{mg} / \mathrm{L}$ with the addition of $15 \mathrm{~g} / \mathrm{L}$ of zeolite and the highest concentration was obtained from control group at $0.36 \mathrm{mg} / \mathrm{L}$ but there is no significant difference among the group ( $>00.05)$. It was mentioned that, the nitrite content should be lower than $0.2 \mathrm{mg} / \mathrm{L}$ (AFCD, 2009). According to PHILMINAQ the nitrite level for hard freshwater species should be lower than $0.1 \mathrm{mg} / \mathrm{L}$ while for freshwater should be lower than $0.5 \mathrm{mg} / \mathrm{L}$. The results of present study were under those values. Meanwhile, for nitrate concentration, it was observed that the application of zeolite decreased obviously the 
level of nitrate in water (Table 2). Addition of $15 \mathrm{~g} / \mathrm{L}$ of zeolite resulted as the lowest concentration of nitrate and there was a significant difference $(p<0.05)$ compared to control group which recorded as the highest concentration.Average nitrate concentration in control, $5 \mathrm{~g} / \mathrm{L}, 10 \mathrm{~g} / \mathrm{L}, 15 \mathrm{~g} / \mathrm{L}$ and $20 \mathrm{~g} / \mathrm{L}$ of zeolite groups were recorded as $7.60 \mathrm{mg} / \mathrm{L}, 4.99 \mathrm{mg} / \mathrm{L}, 4.69$ $\mathrm{mg} / \mathrm{L}, 4.22 \mathrm{mg} / \mathrm{L}$ and $4.98 \mathrm{mg} / \mathrm{L}$ respectively. Nitrate is harmless compare to ammonia and nitrite and its levels are normally stabilized in the 50-100 ppm range (Bhatnagar \& Devi, 2013).

On the other hand, the content of phosphates (total phosphorus and orthophosphates) in the addition of zeolite has significant difference compared to the control. The lowest values were recorded in the addition of $10 \mathrm{~g} / \mathrm{L}$ zeolite for both total phosphorus and orthophosphate at $4.95 \mathrm{mg} / \mathrm{L}$ and $3.83 \mathrm{mg} / \mathrm{L}$. According to Wanchun et al. (2011), the removal of zeolite on phosphorus is increased with the decreased of $\mathrm{pH}$. The removal of phosphorus increases in alkaline conditions, because the $\mathrm{PO}_{4}{ }^{2-}$ may form precipitate with $\mathrm{Ca}^{2+}$ or $\mathrm{Ba}^{2+}$ and there is a relationship between alkalinity. In a pond with higher alkalinity, the $\mathrm{pH}$ shift is reduced (Buttner, 1993). At the end of the experiment, the highest total alkalinity value was recorded in the addition of $10 \mathrm{~g} / \mathrm{L}$ zeolite.This has proven that, the removal of phosphorus by zeolite increase in alkaline condition.

For total hardness, there was a significant difference between the control group and the group with additional of zeolite $(\mathrm{p}<0.05)$. In most waters the concentrations of alkalinity and hardness are similar, but they can be vastly different as alkalinity measures negative ions such as carbonate \& bicarbonate and hardness measures positive ions such as calcium \& magnesium (Buttner, 1993). At the end of the experiment, the lowest value of hardness was recorded at $21.31 \mathrm{mg} / \mathrm{L}$ from control group and the highest value was recorded at $40.03 \mathrm{mg} / \mathrm{L}$ with the addition of $10 \mathrm{~g} / \mathrm{L}$ of zeolite. The recommended ideal value of hardness for fish culture is at least $20 \mathrm{mg} / \mathrm{L}$ and a range of 30-180 mg/L (Bhatnagar \& Devi, 2013). According to Bhatnagar et al. (2004) hardness values less than $20 \mathrm{ppm}$ can causes stress to the fish and $75-150 \mathrm{ppm}$ is optimum for fish culture.

\subsection{Growth Performance Parameter}

The growth performance of the Red Hybrid Tilapia has been determined and data are given in Table 3 for the experimental period of 60 days. At the beginning of the experiments, average weight of fish was $2.7 \pm 0.02 \mathrm{~g}$ for control and all treatments groups.

Table 2. Physico-chemical parameters of aquarium water during the experimental period.

\begin{tabular}{|c|c|c|c|c|c|}
\hline \multirow[t]{2}{*}{ Parameters } & \multicolumn{3}{|c|}{ Treatments of zeolite } & & \\
\hline & Control & $5 \mathrm{~g} / \mathrm{L}$ & $10 \mathrm{~g} / \mathrm{L}$ & $15 \mathrm{~g} / \mathrm{L}$ & $20 \mathrm{~g} / \mathrm{L}$ \\
\hline Temperature $\left({ }^{\circ} \mathrm{C}\right)$ & $25.68 \pm 0.75^{b}$ & $25.99 \pm 0.87^{\mathrm{c}}$ & $\begin{array}{l}25.85 \pm 0.83^{b} \\
c\end{array}$ & $25.76 \pm 0.80^{b}$ & $\begin{array}{l}25.79 \pm 0.86^{\mathrm{b}} \\
\mathrm{c}\end{array}$ \\
\hline $\mathrm{DO}(\mathrm{mg} / \mathrm{L})$ & $2.47 \pm 0.78^{\mathrm{cd}}$ & $2.09 \pm 0.33^{\mathrm{bc}}$ & $2.47 \pm 0.19^{b}$ & $3.05 \pm 0.70^{\mathrm{d}}$ & $2.90 \pm 0.95^{b c}$ \\
\hline $\mathrm{pH}$ & $6.27 \pm 0.83^{\mathrm{bc}}$ & $6.49 \pm 0.82^{c}$ & $6.42 \pm 0.85^{\mathrm{bc}}$ & $6.28 \pm 0.85^{\mathrm{bc}}$ & $6.19 \pm 0.91^{\mathrm{b}}$ \\
\hline Turbidity(NTU) & $11.32 \pm 4.54^{\mathrm{b}}$ & $10.65 \pm 3.92^{b}$ & $14.51 \pm 8.51^{\mathrm{c}}$ & $9.99 \pm 7.22^{\mathrm{b}}$ & $17.55 \pm 7.78^{\mathrm{c}}$ \\
\hline $\mathrm{NH}_{3}-\mathrm{N}(\mathrm{mg} / \mathrm{L})$ & $0.18 \pm 0.05^{\mathrm{c}}$ & $0.17 \pm 0.05^{\mathrm{c}}$ & $0.11 \pm 0.03^{\mathrm{bc}}$ & $0.04 \pm 0.01^{\mathrm{ab}}$ & $0.08 \pm 0.02^{\mathrm{ab}}$ \\
\hline $\mathrm{NO}_{2}(\mathrm{mg} / \mathrm{L})$ & $\begin{array}{l}0.36 \pm 0.043^{b} \\
c\end{array}$ & $0.31 \pm 0.038^{\mathrm{c}}$ & $0.26 \pm 0.038^{\mathrm{b}}$ & $0.23 \pm 0.037^{c}$ & $\begin{array}{l}0.27 \pm 0.038^{b} \\
c\end{array}$ \\
\hline $\mathrm{NO}_{3}(\mathrm{mg} / \mathrm{L})$ & $7.60 \pm 1.38^{\mathrm{c}}$ & $4.99 \pm 0.91^{\mathrm{bc}}$ & $4.69 \pm 1.41^{\mathrm{b}}$ & $4.22 \pm 0.71^{\mathrm{b}}$ & $4.98 \pm 0.77^{\mathrm{bc}}$ \\
\hline Phosphorus & $6.89 \pm 0.31^{\mathrm{d}}$ & $5.68 \pm 0.36^{\mathrm{bc}}$ & $4.95 \pm 0.30^{\mathrm{b}}$ & $5.47 \pm 0.31^{b}$ & $6.28 \pm 0.29^{\mathrm{cd}}$ \\
\hline
\end{tabular}




\begin{tabular}{|c|c|c|c|c|c|}
\hline$(\mathrm{mg} / \mathrm{L})$ & & & & & \\
\hline $\begin{array}{l}\text { Orthophosphate } \\
\text { (mg/L) }\end{array}$ & $5.25 \pm 0.23^{\mathrm{d}}$ & $4.37 \pm 0.33^{\mathrm{bc}}$ & $3.83 \pm 0.26^{\mathrm{b}}$ & $4.67 \pm 0.31^{\mathrm{c}}$ & $4.60 \pm 0.23^{c}$ \\
\hline T. Alkalinity (mg/L) & $\begin{array}{l}41.00 \pm 3.79^{b} \\
c\end{array}$ & $49.41 \pm 5.07^{\mathrm{d}}$ & $\begin{array}{l}50.27 \pm 4.77^{c} \\
\text { d }\end{array}$ & $32.11 \pm 3.60^{\mathrm{b}}$ & $37.50 \pm 4.48^{b}$ \\
\hline T. Hardness (mg/L) & $21.31 \pm 0.63^{\mathrm{b}}$ & $36.25 \pm 3.15^{\mathrm{d}}$ & $40.03 \pm 3.57^{\mathrm{d}}$ & $\begin{array}{l}36.08 \pm 2.28^{c} \\
d\end{array}$ & $30.28 \pm 0.94^{\mathrm{c}}$ \\
\hline
\end{tabular}

-Main effect means within same column followed by same letter has no significant difference at $\mathrm{p}>0.05$ after determined by Tukey's test.

At the end of the experiment, the results showed that, final weights of tilapia kept in aquaria with addition of zeolite are significantly higher than control. As shown in Figure 1, average weight of Red Hybrid Tilapia increased with increasing of zeolite doseas well as days of experimental period. Addition of $20 \mathrm{~g} / \mathrm{L}$ zeolite resulted as the highest weight gain and the lowest value obtained from control group to be at 18.2 \pm 4.2 respectively.In comparison with control, specific growth rate and weight gain in treatments significantly improved. Addition of $20 \mathrm{~g} / \mathrm{L}$ of zeolite also resulted in highest ADW (average daily weight gain) and the difference was significant $(\mathrm{P}<0.05)$ compared with other treatments.Previous study from Ghiasi and Jasour (2012) found that, the final weight of Angel fish (Pterophyllumscalare) with addition of $10 \& 15 \mathrm{~g} / \mathrm{L}$ zeolite were higher compared to control group (without addition of zeolite). Related to the results of current study, addition of $20 \mathrm{~g} / \mathrm{L}$ showed the highest weight gain and $15 \mathrm{~g} / \mathrm{L}$ zeolite resulted in second highest in weight gain of Red Hybrid Tilapia compared to other treatments. According to these findings it can be concluded that addition of $15 \mathrm{~g} / \mathrm{L}$ of zeolite in water not just the best for water quality improvement but was also the best dose for better growth performance of fish. On the other hand, the study performed by Yildirim et al. (2009) showed that, the growth performance of Tilapia zilli fed with fish feed diets containing $2 \%$ of zeolite showed an increase compared to control group. Also, El-Gendy et al. (2015) reported that the addition of zeolite at feeding rate $3 \%$ of body weight resulted in the highest body weight of Nile Tilapia (Oreochromisniloticus). In correlated to these findings, it showed that the addition of zeolite directly in fish diets or addition of zeolite into the water system resulted in better growth performance by the increasing of fish body weight.

\section{Conclusion}

Based on the results obtained in this study, it can be concluded that $15 \mathrm{~g} / \mathrm{L}$ of zeolite was the best dose in reduction of ammonia levels in water. Meanwhile, for the phosphates levels, addition of $10 \mathrm{~g} / \mathrm{L}$ of zeolite was the best among other treatments. In general, improvement of water quality and growth performance of Red Hybrid Tilapia (Oreochromisniloticus) was obtained with the addition of $(5,10,15,20 \mathrm{~g} / \mathrm{L})$ zeolite. However, further research need to be conducted to obtain optimum dosage including the particle size of zeolite.

\section{Acknowledgement}

This work is supported by the Niche Research Grant Scheme (NRGS), Ministry of Higher Education (MOHE). Project no: R/NRGS/A07.00/00303A/002/ 2014/0001.We would like to thank the Ministry of Higher Education (MOHE) for supporting this research grant. 
Table 3. Growth Performance of Red Hybrid Tilapia

\begin{tabular}{lccccc}
\hline Growth parameters & \multicolumn{5}{c}{ Treatments of zeolite } \\
\cline { 2 - 5 } & Control & $5 \mathrm{~g} / \mathrm{L}$ & $10 \mathrm{~g} / \mathrm{L}$ & $15 \mathrm{~g} / \mathrm{L}$ & $20 \mathrm{~g} / \mathrm{L}$ \\
\hline Initial weight $(\mathrm{g})$ & $2.7 \pm 0.01$ & $2.7 \pm 0.01$ & $2.7 \pm 0.01$ & $2.7 \pm 0.01$ & $2.7 \pm 0.01$ \\
\hline Final weight $(\mathrm{g})$ & $20.9 \pm 4.2^{\mathrm{b}}$ & $21.5 \pm 2.6^{\mathrm{b}}$ & $22.3 \pm 1.7^{\mathrm{b}}$ & $22.6 \pm 2.1^{\mathrm{b}}$ & $27.7 \pm 2.8^{\mathrm{c}}$ \\
\hline Weight gain & $18.2 \pm 4.2^{\mathrm{b}}$ & $18.9 \pm 2.6^{\mathrm{b}}$ & $19.6 \pm 1.7^{\mathrm{b}}$ & $19.9 \pm 2.1^{\mathrm{b}}$ & $24.9 \pm 2.8^{\mathrm{c}}$ \\
\hline Initial length $(\mathrm{cm})$ & $2.54 \pm 0.01$ & $2.54 \pm 0.01$ & $2.54 \pm 0.01$ & $2.54 \pm 0.01$ & $2.54 \pm 0.01$ \\
\hline Final length $(\mathrm{cm})$ & $9.5 \pm 1.76^{\mathrm{b}}$ & $9.6 \pm 1.77^{\mathrm{b}}$ & $9.9 \pm 1.94^{\mathrm{bc}}$ & $10.0 \pm 1.82^{\mathrm{bc}}$ & $10.9 \pm 1.97^{\mathrm{c}}$ \\
\hline ADW $(\mathrm{g})$ & $0.303 \pm 0.216^{\mathrm{b}}$ & $0.314 \pm 0.182^{\mathrm{b}}$ & $0.327 \pm 0.211^{\mathrm{b}}$ & $0.331 \pm 0.176^{\mathrm{b}}$ & $0.416 \pm 0.218^{\mathrm{c}}$ \\
\hline SGR $\left(\%\right.$ day $\left.^{-1}\right)$ & $1.47 \pm 0.15^{\mathrm{b}}$ & $1.50 \pm 0.09^{\mathrm{b}}$ & $1.52 \pm 0.05^{\mathrm{b}}$ & $1.53 \pm 0.07^{\mathrm{b}}$ & $1.68 \pm 0.07^{\mathrm{c}}$ \\
\hline
\end{tabular}

-Main effect means within same column followed by same letter has no significant difference at $p>0.05$ after determined by Tukey's test.

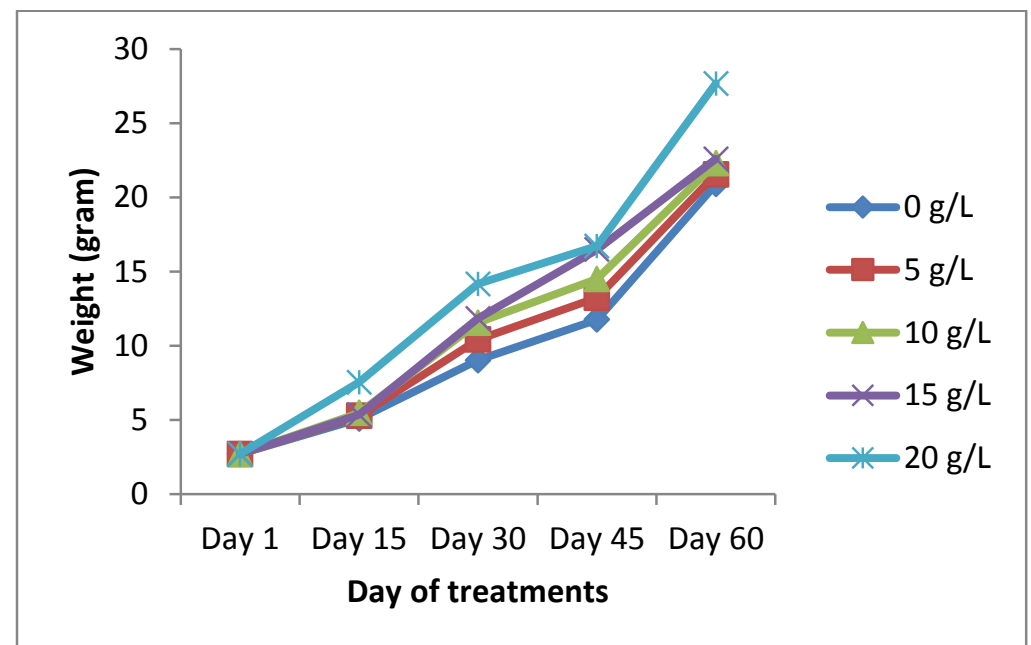

Fig.1. Average weight of Red Hybrid Tilapia (Oreochromisniloticus) measured throughout the experimental period.

\section{References}

[1] Abdel-Rahim, M. M. (2017). Sustainable Use of Natural Zeolites in Aquaculture: A Short Review. AFCD (2009). Good Aquaculture Practices Services: Environmental Management of Pond Fish Culture, Agriculture, Fisheries and Conservation Department.

[2] Bhatnagar, A., Jana, S.N., Garg, S.K. Patra, B.C., Singh, G. and Barman, U.K., (2004), Water quality management in aquaculture, In: Course Manual of summerschool on development of sustainable aquaculture technology in fresh and saline waters, CCS Haryana Agricultural, Hisar (India), pp 203- 210.

[3] Bhatnagar, A., \& Devi, P. (2013). Water quality guidelines for the management of pond fish culture. International Journal of Environmental Sciences, 3(6), 1980.

[4] Buttner, J. K. (1993). Introduction to water chemistry in freshwater aquaculture. Danabas, D., \& Altun, T. (2011). Effects of zeolite (clinoptilolite) on some water and growth parameters of rainbow trout (Oncorhynchus mykiss Walbaum, 1792). Aquaculture, 6, 10. 
[5] El-Gendy, M., Gouda, A., \& Shehab El-Din, M. (2015). Effect of zeolite on feeding rates and growth performance for nile tilapia (Oreochromis niloticus). International Journal of Scientific Research in Agricultural Sciences, 2, 18-24.

[6] Emadi, H., Nezhad, J., \& Pourbagher, H. (2001). In vitro comparison of zeolite (clinoptilolite) and activated carbon as Ammonia absorbants in fish culture. Naga, The ICLARM Quarterly, 24(1-2), 18-20.

[7] FAO (2013). The State of Food Insecurity in the World: The multiple dimensions of food security.FAO, Rome, 214 pp.

[8] Farhangi, M., \& Rostami-Charati, F. (2012). Increasing of survival rate to Acipenser persicus by added clinoptilolite zeolite in acute toxicity test of ammonia. Aquaculture, Aquarium, Conservation \& Legislation International Journal of the Bioflux Society, 5, 18-22.

[9] Ghasemi, Z., Sourinejad, I., Kazemian, H., \& Rohani, S. (2016). Application of zeolites in aquaculture industry: a review. Reviews in Aquaculture.

[10] Ghiasi, F., \& Jasour, M. (2012). The effects of natural zeolite (clinoptilolte) on water quality, growth performance and nutritional parameters of fresh water aquarium fish, angel (Pterophyllum scalare). International Journal of Research in Fisheries and Aquaculture, 2(3), 22-25.

[11] Huang, H., Xiao, X., Yan, B., \& Yang, L. (2010). Ammonium removal from aqueous solutions by using natural Chinese (Chende) zeolite as adsorbent. Journal of Hazardous materials, 175(1), 247-252.

[12] Mazloomi, F., \& Jalali, M. (2016). Ammonium removal from aqueous solutions by natural Iranian zeolite in the presence of organic acids, cations and anions. Journal of Environmental Chemical Engineering, 4(1), 240-249.

[13] Mokhtari-Hosseini, Z. B., Kazemiyan, E., Tayebee, R., \& Shenavaei-Zare, T. (2016). Optimization of ammonia removal by natural zeolite from aqueous solution using response surface methodology. Hemijska industrija, 70(1), 21-29.

[14] Oz, M., Sahin, D., \& Oral, O. (2016). The Effect of Natural Zeolite Clinoptilolite on Aquarium Water Conditions. Hacettepe J. Biol. \& Chem, 44(2), 205-208.

[15] PHILMINAQ. Annex 2. Water Quality Criteria and Standards for Freshwater and Marine Aquaculture. Mitigating Impact from Aquaculture in Philippines.

[16] Popma, T. (1999). Tilapia: life history and biology: Southern Regional Aquaculture Center.

[17] Wanchun, T., Qiuyun, W., Yunbo, W., \& Zhengke, P. (2011). Adsorption of nitrogen and phosphorus on natural zeolite and its influencing factors. Paper presented at the Computer Distributed Control and Intelligent Environmental Monitoring (CDCIEM), 2011 International Conference on Measuring Technology and Mechatronics Automation.

[18] Yıldırım, Ö., Türker, A., \& Şenel, B. (2009). Effects of natural zeolite (Clinoptilolite) levels in fish diet on water quality, growth performance and nutrient utilization of Tilapia (Tilapia zillii) fry. Fresenius Environmental Bulletin, 18(9), 1567-1571.

[19] Zhang, M., Zhang, H., Xu, D., Han, L., Niu, D., Tian, B., Zhang, J., Zhang, L., \& Wu, W. (2011). Removal of ammonium from aqueous solutions using zeolite synthesized from fly ash by a fusion method. Desalination, 271(1-3), 111-121.

[20] Zhou, L., \& Boyd, C. E. (2014). Total ammonia nitrogen removal from aqueous solutions by the natural zeolite, mordenite: A laboratory test and experimental study. Aquaculture, 432, 252-257. 